\title{
PENGUNGKAPAN PERTANGGUNGJAWABAN KEUANGAN PARTAI POLITIK
}

\author{
Isnani Yuli Andini ${ }^{1}$ \\ Dedy Arfiyanto ${ }^{2}$ \\ M. Munir Syam $\mathrm{AR}^{3}$ \\ Fakultas Ekonomi dan Bisnis, Universitas Wiraraja, Indonesia \\ ${ }^{1}$ lia@wiraraja.ac.id \\ ${ }^{2}$ mrdego.ar@gmail.com \\ 3munirsyam@wiraraja.ac.id
}

\begin{abstract}
Political parties are required to make improvements in building transparency and accountability. Developing political ethics in financial management that stands on the values of accountability and transparency. The purpose of this study is to determine the party's financial governance including disclosure of financial accountability. Research results obtained regarding the accountability and financial transparency of the Gerindra party began to apply according to standards. Gerindra party financial management has also begun to be accessed by all parties through the party's official website, so that in 2014 the Gerindra party was named the Public Information Category for Political Parties by the Central Information Commission (KIP) as well as the results of the Indonesia Survey Center (ISC) survey which states that Gerindra is a party which is perceived as clean of corruption cases. With this title the Gerindra Party became the political party that won the third most national votes in the 2019 general election.
\end{abstract}

Keywords: Accountability, Finance, Political Parties.

\section{PENDAHULUAN}

Akuntabilitas dan transparansi keuangan partai politik selalu menjadi isu hangat dan menarik untuk di kaji. Persoalan keuangan partai politik hingga saat ini menjadi tantangan sistem demokrasi. Apalagi pada Tahun 2019 menjadi tahun politik dimana pemilihan dewan legislatif mulai tingkat Kabupaten, Provinsi hingga Dewan Legislatif Republik Indonesia bahkan pemilihan Calon Presiden dan Wakil Presisiden 2019-2023.

Peraturan Standar Akuntansi Keuangan (PSAK) No. 45 juga menjelaskan bahwa "setiap organisasi nirlaba harus menyajikan laporan keuangannya, sehingga dapat dinilai dan dievaluasi apakah pelaporan keuangan yang dilakukan oleh partai sudah akuntabel dan berdasarkan peraturan yang telah ditetapkan". Untuk mewujudkan akuntabilitas dan transparansi keuangan partai dirutuhkan waktu yang cukup lama dan perlu dilakukan secara kontinyu dari berbagai pihak, baik pengurus partai politik maupun pemerintah. Partai Gerindra sebagai salah satu partai politik yang lolos verifikasi Komisi Pemilihan Umum di tahun 2014 Komisi Informasi Pusat (KIP) memberikan penilaian peringkat I dengan kategori partai politik dengan keterbukaan Informasi Publik serta hasil

PERFORMANCE : Jurnal Bisnis \& Akuntansi Volume 10, No.1,Maret 2020 
survei Indonesia Survey Center (ISC) yang menyatakan bahwa Gerindra menjadi partai yang dipersepsikan bersih dari kasus korupsi. Dari beberapa paparan tersebut, peneliti tertaril untuk mengkaji transparansi dan akuntabilitas keuangan partai Gerindra dalam hal pertanggungjawaban dan pelaporan keuangannya yang dihasilkan yang tentunya mengacu pada aturan maupun perundang-undangan yang berlaku. Tujuan dalam penelitian ini yaitu untuk menganalisis pertanggungjawaban dan transparansi pengelolaan keuangan partai Gerindra.

\section{TINJAUAN PUSTAKA}

Partai Politik

Menurut Huntington dan Nelson (1990:21) partai adalah peroranganperorangan yang mengidentifikasikan diri dengan organisasi formal yang sama yang berusaha untuk meraih atau mempertahankan kontrol atas bidangbidang esekutif dan legislatif pemerintah.

\section{Akuntabilitas}

Ludani dkk (2015) mengatakan pelaksanaan akuntabilitas perlu memperhatikan asas-asas dalam akuntabilitas yaitu :

a. Komitmen pimpinan dalam melakukan pengelolaan pelaksanaan misi agar akuntabel

b. Menunjukkan tingkat pencapaian tujuan dan sasaran yang ditetapkan c. Berorientasi pada pencapaian misi dan visi dan hasil manfaat yang diperoleh

d. Jujur, obyektif, transparan dan inovatif.

\section{Transparansi}

Menurut Meutia dan Nurfitriana (2011) transparansi merupakan konsep yang sangat penting sejalan dengan semakin kuatnya keinginan untuk mengembangkan praktik good governance. Praktik good governance mensyaratkan adanya transparansi dalam proses penyelenggaraan pemerintah secara keseluruhan. Pemerintah dituntut untuk terbuka dan menjamin akses stakeholders terhadap berbagai informasi mengenai proses kebijakan publik, alokasi anggaran untuk pelaksanaan kebijakan, serta pemantauan dan evaluasi terhadap pelaksanaan kebijakan.

\section{METODE PENELITIAN}

Pendekatan penelitian yang digunakan dalam penelitian ini adalah pendekatan kualitatif. Objek yang menjadi penelitian ini adalah salah satu partai politik peserta pemilu tahun 2019 yaitu Partai Gerakan Indonesia Raya yang pernah memperoleh peringkat 1 kategori keterbukaan informasi publik. 
Metode pengumpulan data yang digunakan peneliti dalam penelitian ini adalah:

1. Wawancara

Wawancara digunakan sebagai teknik pengumpulan data dengan mewawancarai 1 (satu) informan merupakan kader partai Geindra. Yaitu Ahmad Zahidi, S.PdI beralamatkan di Desa Pakandangan Sangrah Kecamatan Bluto Kabupaten Sumenep. Menduduki jabatan sebagai Sekretaris Dewan Pimpinan Cabang Partai Gerindra Kabupaten Sumenep.

2. Studi Pustaka

Yaitu penelitian yang dilakukan dengan cara mengumpulkan, membaca dan mempelajari literatur referensi dari jurnal, makalah, bukubuku dan peraturan perundangundangan yang relevan dengan permasalahan yang dikaji untuk mendapatkan kejelasan konsep dalam upaya penyusunan landasan teori yang berguna dalam pembahasan.

3. Studi Website.

Akuntabilitas dan transparansi suatu organisasi ditunjukkan dengan bisa diaksesnya informasi laporan pertanggung jawaban keuangan yang bisa di akses oleh siapapun dan dimanapun. Studi website yang dimaksud merupakan website resmi partai Gerindra pada laman

http://partaigerindra.or.id/

\section{Deskripsi Hasil Penelitian}

\section{Hasil Pemilihan Umum Tahun 2019}

Berdasarkan Keputusan Komisi

Pemilihan Umum Republik Indonesia

Nomor 1318/PL.01.9-

Kpt/06/KPU/VIII/2019 tentang

Penetapan Calon terpilih anggota Dewan Perwakilan Rakyat dalam Pemilihan Umum Tahun 2019 bahwa calon terpilih Anggota Dewan Perwakilan Rakyat Pemilihan Umum Tahun 2019 sebanyak 78 orang (dpr.go.id, 2019).

Berikut perolehan suara 16 partai politik diurutkan berdasarkan perolehan kursi terbanyak (Kompas.com, 2019):

1. PDI-P: 128 kursi Jumlah suara: 27.503.961 (19,33 persen) Status: Memenuhi ambang batas.

2. Golkar: 85 kursi Jumlah suara: 17.229.789 (12,31 persen) Status: Memenuhi ambang batas.

3. Gerindra: 78 kursi Jumlah suara: 17.596.839 (12,57 persen) Status: Memenuhi ambang batas.

4. Nasdem: 59 kursi Jumlah suara: 12.661.792 (9,05 persen) Status: Memenuhi ambang batas.

5. PKB: 58 kursi Jumlah suara: 13.570.970 (9,69 persen) Status: Memenuhi ambang batas.

6. Demokrat: 54 kursi Jumlah suara: 10.876.057 (7,77 persen) Status: Memenuhi ambang batas. 
7. PKS: 50 kursi Jumlah suara:

11.493.663 (8,21 persen) Status:

Memenuhi ambang batas.

8. PAN: 44 kursi Jumlah suara:

9.572.623 (6,84 persen) Status:

Memenuhi ambang batas.

9. PPP: 19 kursi Jumlah suara:

6.323.147 (4,52 persen) Status:

Memenuhi ambang batas.

10. 10. Berkarya: 0 kursi Jumlah suara: 2.902.495 (2,09 persen) Status:

Tidak memenuhi ambang batas.

11. PSI: 0 kursi Jumlah suara:

2.650.361(1,85 persen) Status:

Tidak memenuhi ambang batas.
12. Hanura: 0 kursi Jumlah suara: 2.161.507 (1,54 persen) Status:

Tidak memenuhi ambang batas.

13. PBB: 0 kursi Jumlah suara: $1.990 .848(0,79$ persen $)$ Status:

Tidak memenuhi ambang batas.

14. Perindo: 0 kursi Jumlah suara: 3.738.320 (2,07 persen) Status:

Tidak memenuhi ambang batas.

15. PKPI: 0 kursi Jumlah suara: 312.775 (0,22 persen) Status: Tidak memenuhi ambang batas.

16. Garuda: 0 kursi Jumlah suara: $702.536(0,5$ persen $)$ Status: Tidak memenuhi ambang batas.

\section{Gambar 1.}

Grafik Perolehan Kursi DPR RI Partai Politik pada Pemilu Tahun 2019 Perolehan Kursi Parpol di DPR RI 2019-2024

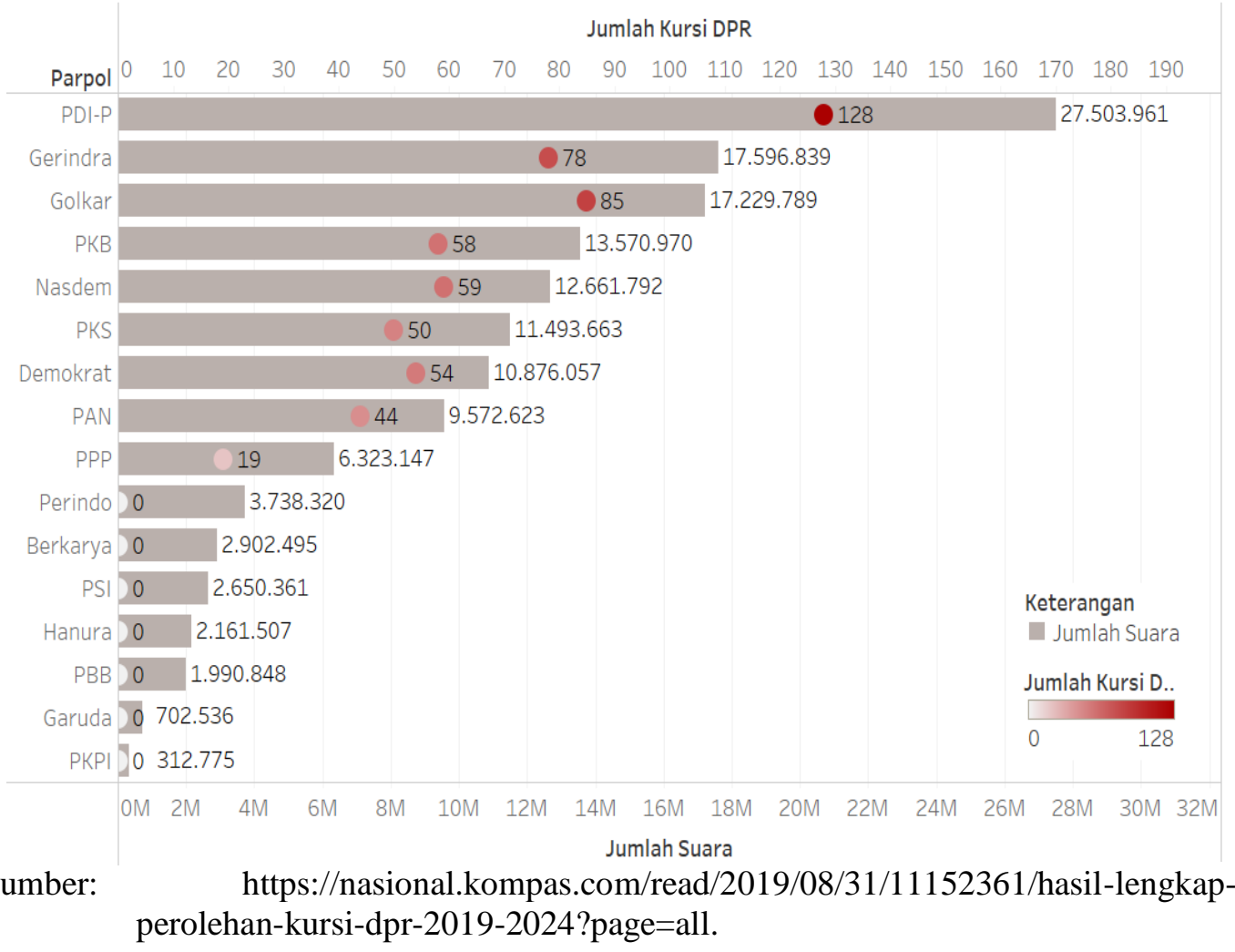

PERFORMANCE : Jurnal Bisnis \& Akuntansi Volume 10, No.1,Maret 2020 
Sumber Pendapatan Partai Politik

Menurut Undang-undang Republik

Indonesia Nomor 2 Tahun 2011 tentang

Perubahan atas Undang-undang Nomor

2 Tahun 2008 tentang partai politik pasal 34 ayat 1 yang berbunyi keuangan partai politik bersumber dari:

a. Iuran anggota;

b. Sumbangan yang sah menurut hukum; dan

c. Bantuan keuangan dari Anggaran Pendapatan dan Belanja Negara /
Anggaran Pendapatan dan Belanja

Daerah.

Menurut Peraturan Pemerintah Republik Indonesia Nomor 1 Tahun 2018 tentang Perubahan Kedua atas Peraturan Pemerintah Nomor 5 Tahun 2009 tentang Bantuan Keuangan Kepada Partai Politik pasal 5 ayat 1 yang berbunyi besaran nilai bantuan keuangan kepada partai politik tingkat pusat yang mendapatkan kursi di DPR sebagaimana dimaksud dalam pasal 2 ayat (3) sebesar Rp. 1.000 (seribu rupiah) per suara sah.

Tabel 1.

Pengaturan Sumber Keuangan Partai Politik dalam empat undang-undang

\begin{tabular}{|c|c|c|c|c|}
\hline ISU & $\begin{array}{c}\text { UU } \\
\text { No.2/1990 }\end{array}$ & $\begin{array}{c}\mathrm{UU} \\
\text { No.31/2002 }\end{array}$ & $\begin{array}{c}\mathrm{UU} \\
\text { No.2/2008 }\end{array}$ & UU No.2/2011 \\
\hline Sumber & $\begin{array}{l}\text { Iuran anggota; } \\
\text { Sumbangan; } \\
\text { Usaha lain } \\
\text { yang sah; } \\
\text { Bantuan } \\
\text { negara. }\end{array}$ & $\begin{array}{l}\text { Iuran anggota; } \\
\text { Sumbangan; } \\
\text { Bantuan } \\
\text { negara }\end{array}$ & $\begin{array}{l}\text { Iuran anggota; } \\
\text { Sumbangan; } \\
\text { Bantuan } \\
\text { negara. }\end{array}$ & $\begin{array}{l}\text { Iuran anggota; } \\
\text { Sumbangan; } \\
\text { Bantuan } \\
\text { negara. }\end{array}$ \\
\hline $\begin{array}{l}\text { Batasan } \\
\text { Sumbangan }\end{array}$ & $\begin{array}{l}\text { Perseorangan } \\
\text { maksimal Rp } \\
15 \text { juta; } \\
\text { Perusahaan } \\
\text { maksimal Rp } \\
150 \text { juta. }\end{array}$ & $\begin{array}{l}\text { Perseorangan } \\
\text { maksimal Rp } \\
200 \text { juta; } \\
\text { Perusahaan } \\
\text { maksimal Rp } \\
800 \text { juta. }\end{array}$ & $\begin{array}{l}\text { Perseorangan } \\
\text { bukan anggota } \\
\text { maksimal Rp } \\
1 \text { miliar; } \\
\text { Perusahaan } \\
\text { maksimal Rp } \\
4 \text { miliar. }\end{array}$ & $\begin{array}{l}\text { Perseorangan } \\
\text { bukan anggota } \\
\text { maksimal Rp } \\
1 \\
\text { miliar;Perusah } \\
\text { aan maksimal } \\
\text { Rp 7,5 miliar. }\end{array}$ \\
\hline $\begin{array}{l}\text { Penerima } \\
\text { Bantuan } \\
\text { Negara }\end{array}$ & $\begin{array}{l}\text { Partai politik } \\
\text { yang } \\
\text { memperoleh } \\
\text { suara dalam } \\
\text { pemilu. }\end{array}$ & $\begin{array}{l}\text { Partai politik } \\
\text { yang mempu } \\
\text { nyai kursi di } \\
\text { DPR/DPRD. }\end{array}$ & $\begin{array}{l}\text { Partai politik } \\
\text { yang mempu } \\
\text { nyai kursi di } \\
\text { DPR/DPRD. }\end{array}$ & $\begin{array}{l}\text { Partai politik } \\
\text { yang } \\
\text { mempunyai } \\
\text { kursi di } \\
\text { DPR/DPRD. }\end{array}$ \\
\hline
\end{tabular}

Sumber: (Supriyanto, 2012) 
Tabel 4.1 menunjukkan perubahan pengaturan sumber keuangan partai politik sebagaimana diatur oleh UU No. 2/1999, UU No. 31/2002, UU No. 2/2008, dan UU No.2/2011. Iuran anggota selalu ditempatkan sebagai sumber keuangan utama partai politik. Sementara dari undang-undang nomor 2 tahun 2019 hingga undang-undang nomor 2 tahun 2011 selalu terjadi peningkatan sumbangan perseorangan maupun perusahaan. Tentang penerima bantuan keuangan negara terjadi perubahan penting pada UU No. 31/2002 yang mengubah kriteria partai politik penerima sumbangan.

Tabel 2

Pengaturan Bantuan Keuangan Partai Politik dalam Empat Undang-undang

\begin{tabular}{|c|c|c|c|c|}
\hline ISU & UU No.2/1990 & $\begin{array}{c}\text { UU } \\
\text { No.31/2002 }\end{array}$ & UU No.2/2008 & UU No.2/2011 \\
\hline $\begin{array}{l}\text { Kriteria Pene } \\
\text { rima }\end{array}$ & $\begin{array}{l}\text { Partai politik } \\
\text { yang mem } \\
\text { peroleh suara } \\
\text { dalam pemilu. }\end{array}$ & $\begin{array}{l}\text { Partai politik } \\
\text { yang mempu } \\
\text { nyai kursi di } \\
\text { DPR/DPRD. }\end{array}$ & $\begin{array}{l}\text { Partai politik } \\
\text { yang } \\
\text { mempunyai } \\
\text { kursi di } \\
\text { DPR/DPRD. }\end{array}$ & $\begin{array}{l}\text { Partai politik } \\
\text { yang } \\
\text { mempunyai } \\
\text { kursi di } \\
\text { DPR/DPRD. }\end{array}$ \\
\hline $\begin{array}{l}\text { Metode Pene } \\
\text { tapan Jumlah }\end{array}$ & (tidak diatur) & $\begin{array}{l}\text { Secara } \\
\text { propors ional } \\
\text { berdasar kan } \\
\text { jumlah kursi. }\end{array}$ & $\begin{array}{l}\text { Secara } \\
\text { proporsional } \\
\text { berdasarkan } \\
\text { jumlah } \\
\text { perolehan suara. }\end{array}$ & $\begin{array}{l}\text { Secara proporsio } \\
\text { nal berdasarkan } \\
\text { jumlah } \\
\text { perolehan suara. }\end{array}$ \\
\hline Peruntukan & (tidak diatur) & (tidak diatur) & $\begin{array}{l}\text { Pendidikan } \\
\text { politik dan } \\
\text { operasional } \\
\text { sekretariat. }\end{array}$ & $\begin{array}{l}\text { Diprioritaskan } \\
\text { untuk } \\
\text { pendidikan } \\
\text { politik. }\end{array}$ \\
\hline $\begin{array}{l}\text { Laporan } \\
\text { Pertang-gung } \\
\text { jawaban }\end{array}$ & (tidak diatur) & (tidak diatur) & $\begin{array}{l}\text { Menyampaikan } \\
\text { laporan pertang } \\
\text { gungjawaban } \\
\text { kepada } \\
\text { pemerintah } \\
\text { setelah diperiksa } \\
\text { BPK. }\end{array}$ & $\begin{array}{l}\text { Menyampaikan } \\
\text { laporan pertang } \\
\text { gungjawaban } \\
\text { kepada BPK } \\
\text { untuk diaudit. }\end{array}$ \\
\hline $\begin{array}{l}\text { Sanksi } \\
\text { ketaatan } \\
\text { Penyam } \\
\text { paian } \\
\text { Laporan } \\
\text { Pertanggung } \\
\text { jawaban }\end{array}$ & (tidak diatur) & (tidak diatur) & $\begin{array}{l}\text { Penghentian } \\
\text { bantuan sampai } \\
\text { laporan diterima } \\
\text { pemerintah. }\end{array}$ & $\begin{array}{l}\text { Penghentian } \\
\text { bantuan sampai } \\
\text { laporan diterima } \\
\text { pemerintah }\end{array}$ \\
\hline $\begin{array}{l}\text { Pengaturan } \\
\text { Pelaksanaan }\end{array}$ & $\begin{array}{l}\text { Peraturan } \\
\text { Pemerintah }\end{array}$ & $\begin{array}{l}\text { Peraturan } \\
\text { Pemerintah }\end{array}$ & $\begin{array}{l}\text { Peraturan } \\
\text { Pemerintah }\end{array}$ & $\begin{array}{l}\text { Peraturan } \\
\text { Pemerintah }\end{array}$ \\
\hline
\end{tabular}

Sumber: (Supriyanto, 2012) 
Tabel 4.2 memperlihatkan bagaimana setiap undang-undang mengatur tentang bantuan keuangan partai politik. Jika UU No. 2/1999 memberikan bantuan keuangan kepada partai politik yang memperoleh suara dalam pemilu, tiga undang-undang berikutnya mengalihkan bantuan kepada partai yang memiliki kursi di DPR/DPRD. Lalu, UU No. 2/2008 juga menandai perubahan lain, yang menyebut penggunaan bantuan keuangan untuk pendidikan politik dan mewajibkan laporan penggunaan bantuan keuangan diaudit oleh BPK. Meskipun UU No. 2/1999 menentukan kriteria bahwa partai politik yang menerima sumbangan adalah peraih suara dalam pemilu, tetapi undangundang ini tidak menentukan metode penentuan besaran bantuan. Baik UU No. 2/1999 maupun UU No. 31/2002 sama-sama tidak menyebutkan peruntukan bantuan negara, pembuatan laporan pertanggungjawaban atas penggunaan dana bantuan negara, serta sanksi terhadap partai politik yang tidak menyampaikan

laporan pertanggungjawaban penggunan dana bantuan negara. Namun, kekosongan pengaturan soal tersebut kemudian dipenuhi oleh UU No. 2/2008 dan UU No. 2/2011.

Menurut hasil audit Badan Pemeriksa Keuangan Republik Indonesia dengan surat nomor:30/S/VII-XVIIII/04/2019 tentang hasil pemeriksaan atas pertanggungjawaban penerimaan dan pengeluaran bantuan keuangan DPP Partai Gerakan Indonesia Raya dari APBN Tahun 2018. Berdasarkan hasil pemeriksaan, pertanggungjawaban penerimaan Bantuan Partai Politik yang bersumber dari APBN Tahun 2018 DPP Partau Gerindra menunjukkan bahwa:

1. Nomor rekening yang digunakan untuk menampung bantuan partai politik telah sesuai dengan nomor rekening parati politik yang diajukan kepada Kemendagri.

2. Jumlah bantuan partai politik yang diterima telah sesuai dengan jumlah bantuan partai politik yang disalurkan oleh Kemendagri.

3. Pertanggungjawaban bantuan partai politik telah didukung dengan bukti yang lengkap.

4. Penggunaan bantuan partai politik telah diprioritaskan untuk pelaksanaan pendidikan politik bagi anggota parpol dan masyarakat.

Hasil kesimpulan BPK menyatakan bahwa pertanggungjawaban penerimaan dan pengeluaran bantuan partai politik yang bersumber dari APBN Tahun 2018 pada DPP Partai Gerakan Indonesia Raya telah sesuai dengan kriteria peraturan perundang-undangan yang berlaku.

Partai Gerindra menurut hasil perhitungan sah pemilu DPR periode 
FAKULTAS EKONOMI DAN BISNIS UNIVERSITAS WIRARAJA - MADURA

2014 ditetapkan dengan Surat

Keputusan Komisi Pemilihan Umum

Pusat Nomor 574/Kpts/KPU/Tahun

2014 tentang Penetapan Perolehan suara sah partai politik dan calon anggota

DPR dalam Pemilihan Umum Tahun

2014 dan surat Keputusan Komisi

Pemilihan Umum Pusat Nomor

416/Kpts/KPU/Tahun 2014 tanggal 14

Mei 2014 tentang penetapan hasil

pemilihan umum, perolehan kursi dan calon terpilih anggota DPR pemilihan umum tahun 2014. Berdasarkan kedua surat keputusan tersebut, perolehan suara dan kursi DPP Partai Gerindra adalah $\quad 14.750 .043 .000,00 \quad(14.750 .043$ suara x Rp. 1000,00). Jadi DPP Partai Gerindra menerima bantuan keuangan partai politik dari Kemendagri sebesar Rp. 14.750.043.000,00.

Pencatatan dana keuangan partai politik

Partai politik didirikan tidak untuk mencari laba namun bertujuan untuk memperjuangkan keinginan luhur para anggotanya dalam kehidupan bermasyarakat, berbangsa dan bernegara. Akuntabilitas dan transparansi merupakan Prinsip pokok keuangan partai politik, Partai politik diharapkan bersikap terbuka dalam setiap pengelolaan keuangan. Tujuan membuka laporan keuangan partai politik kepada publik guna menguji prinsip akuntabilitas serta memastikan tanggung jawab partai. Pertanggung jawaban keuangan partai dari proses penerimaan hingga membelanjakan dana partai politik itu rasional, sesuai etika dan tidak melanggar peraturan yang telah ditetapkan.

Kebanyakan organisasi nirlaba menggunakan beberapa parameter tunggal sebagai ukuran keberhasilannya, seperti jumlah dana sumbangan yang diperoleh, pertumbuhan jumlah anggota, jumlah pengunjung, jumlah orang yang dilayani dan biaya overhead mampu diminimalisasikannya (Bastian, 2017). Perlakuan akuntansi dan pelaporan keuangan partai mengacu pada PSAK No.45, yaitu unsur laporan keuangan dari PSAK No.45 adalah laporan posisi keuangan, laporan aktivitas, laporan arus kas, dan catatan atas laporan keuangan.

Keberhasilan suatu partai politik diukur dengan banyaknya suara yang diperoleh dari pemilihan umum, hal ini menjadikan salah satu karakteristik partai politik yang membedakannya dengan organisasi nirlaba lainnya, yaitu partai politik memperjuangkan kepentingan baik anggota, bangsa dan negara melalui kegiatan pemilu. Jika partai politik tidak mendapatkan kursi karena calon yang diajukan tidak terpilih maka akan berdampak pada tidak adanya bantuan dana hibah dari pemerintah dan bantuan dana hibah sangat tergantung pada jumlah anggota 
yang yang terpilih untuk duduk di DPR

(Wijaya dan Abdullah, 2014).

Tata cara pengajuan bantuan keuangan partai politik sebagaimana diatur dalam Peraturan Menteri Dalam Negeri nomor No. 24 Tahun 2009 tentang Tata Cara Pelaporan Bantuan Keuangan Partai Politik Bab IV pasal 12 ayat 1 yang berbunyi "Pengajuan surat permohonan bantuan keuangan partai politik tingkat Nasional disampaikan secara tertulis oleh Pengurus partai politik ditandatangani oleh Ketua Umum dan Sekretaris Jenderal atau sebutan lain yang terdaftar kepada Menteri Dalam Negeri untuk menyalurkan dana bantuan keuangan ke rekening kas umum partai politik dengan menggunakan kop surat dan cap stempel partai politik dengan melampirkan kelengkapan administrasi berupa: (a) foto copy Akte Notaris Pendirian yang memuat anggaran dasar dan anggaran rumah tangga partai politik; (b) foto copy Surat Keterangan kepengurusan partai politik yang telah terdaftar dan disahkan oleh Departemen Hukum dan Hak Asasi Manusia yang dilegalisir oleh pejabat Departemen
Hukum dan Hak Asasi Manusia; (c) foto copy Surat Keterangan NPWP; (d) nomor rekening kas umum partai politik yang dibuktikan dengan pernyataan pembukaan rekening dari bank yang bersangkutan; (e) surat keterangan autentikasi hasil penetapan perolehan kursi dan suara hasil pemilihan umum DPR-RI yang dilegalisir oleh Ketua atau Wakil Ketua atau Sekretaris Jenderal Komisi Pemilihan Umum; (f) rencana penggunaan dana bantuan keuangan partai politik; (g) laporan realisasi penerimaan dan penggunaan bantuan keuangan tahun anggaran sebelumnya; dan (h) surat pernyataan partai politik yang menyatakan bersedia dituntut sesuai peraturan perundang-undangan apabila memberikan keterangan yang tidak benar yang ditandatangani Ketua Umum dan Sekretaris Jenderal atau sebutan lainnya di atas materai dengan menggunakan kop surat partai politik".

Berikut laporan pertanggungjawaban pengeluaran bantuan keuangan partai Gerakan Indonesia Raya tahun 2018 sebagaimana tabel 4.3. 
Tabel 3.

Partai Gerakan Indonesia Raya

Laporan Pertanggungjawaban Pengeluaran Bantuan Keuangan

Tahun 2018

\begin{tabular}{|c|c|c|c|}
\hline NO & JENIS PENGELUARAN & REALISASI & $\%$ \\
\hline $\mathbf{A}$ & PENDIDIKAN POLITIK & 13.692.873.750 & $\mathbf{9 2 , 8 3 \%}$ \\
\hline 1 & Seminar & 13.692 .873 .750 & \\
\hline 2 & Lokakarya & - & \\
\hline 3 & Dialog Interaktif & - & \\
\hline 4 & Sarasehan & - & \\
\hline 5 & Workshop & - & \\
\hline 6 & $\begin{array}{l}\text { Kegiatan pertemuan lainnya sesuai } \\
\text { tugas dan fungsinya }\end{array}$ & - & \\
\hline \multirow[t]{22}{*}{ B } & OPERASIONAL SEKRETARIAT & 1.057.169.250 & $7,17 \%$ \\
\hline & 1. Administrasi Umum & & \\
\hline & A. Keperluan ATK & 85.444 .701 & \\
\hline & B. Rapat internal sekretariat & 104.751 .635 & \\
\hline & $\begin{array}{l}\text { C. Ongkos perjalanan dinas dalam } \\
\text { rangka mendukung kegiatan } \\
\text { operasional sekretariat }\end{array}$ & 182.671 .111 & \\
\hline & $\begin{array}{l}\text { D. Transport dalam rangka } \\
\text { mendukung kegiatan } \\
\text { operasional sekretariat }\end{array}$ & 11.753 .560 & \\
\hline & $\begin{array}{l}\text { E. Pengadaan inventaris berupa } \\
\text { peralatan kantor, antara lain } \\
\text { furniture, komputer, mesin } \\
\text { fotokopi }\end{array}$ & 63.631 .600 & \\
\hline & F. Sewa kantor & - & \\
\hline & $\begin{array}{l}\text { G. Honor tenaga administrasi } \\
\text { sekretariat yang berkompeten } \\
\text { di bidang pengelolaan } \\
\text { keuangan }\end{array}$ & - & \\
\hline & 2. Langganan daya dan jasa & & \\
\hline & A. Telepon dan listrik & 552.057 .409 & \\
\hline & B. Air minum & 35.179 .000 & \\
\hline & C. Jasa dan pos giro & 2.027 .000 & \\
\hline & D. Surat menyurat & - & \\
\hline & E. Media cetak dan elektronik & 3.090 .000 & \\
\hline & 3. Pemeliharaan data dan arsip & & \\
\hline & A. Penyimpanan data elektronik & - & \\
\hline & B. Penyimpanan data manual & - & \\
\hline & 4. Pemeliharaan peralatan kantor & & \\
\hline & $\begin{array}{l}\text { A. Pemeliharaan peralatan } \\
\text { elektronik sekretariat }\end{array}$ & 16.563 .234 & \\
\hline & $\begin{array}{l}\text { B. Pemeliharaan peralatan } \\
\text { inventaris kantor dan } \\
\text { sekretariat }\end{array}$ & & \\
\hline & TOTAL A + B & 14.750.043.000 & $100 \%$ \\
\hline
\end{tabular}

Sumber: Laporan audit BPK Tahun 2018 
Guna mendukung hal tentang akuntabilitas dan transparansi pengelolaan keuangan partai. Peneliti berusaha mewawancarai kader partai Gerindra yang juga DPC Partai Gerindra Kabupaten Sumenep tentang beberapa hal meliputi pedoman pengelolaan partai serta pertanggungjawaban keuangan.

Berikut hasil wawancara peneliti:

Apakah Partai Gerindra selalu mematuhi dan menjadikan pedoman setiap peraturan tentang pengelolaan organisasi?

" partai Gerindra merupakan partai yang transparan dan selalu berjalan sesuai aturan yang telah ditetapkan dalam pengelolaannya, baik sisi administratif maupun pelaporan keuangannya. Hal ini sering ditekankan oleh pimpinan pusat untuk selalu berpedoman pada peraturan yang telah ditetapkan salah satunya Undang-undang No.2 tahun 2011 tentang Partai Politik."

Bagaimana dengan pengelolaan dan pertanggungjawaban keuangan partai di daerah?

"Partai Gerindra selalu mengedepankan akuntabilitas dan transparansi. Hal ini sering disampaikan ketika pertemuan seluruh kader partai Gerindra Daerah se Indonesia. Dalam pengelolaan keuangan harus selalu berpedoman pada peraturan yang telah ditetapkan. Untuk bantuan keuangan, peraturan yang di pedomani meliputi Peraturan Pemerintah No. 1 Tahun 2018 tentang bantuan keuangan partai politik serta Peraturan Menteri Dalam Negeri nomor No. 24 Tahun 2009 tentang Tata Cara Pelaporan Bantuan Keuangan Partai Politik."
Apakah pertanggungjawaban keuangan partai Gerindra sudah transparan?

"setau saya transparan itu bias diakses oleh semua pihak, pengelolaan pertanggungjawaban keuangan partai semuanya sudah mempedomani aturan yang telah ditetapkan termasuk pertanggungjawaban di daerah. Untuk laporan pertanggungjawaban Partai Gerindra pada tingkat pusat sudah bisa di akses, namun di Daerah masih belum, sehingga jika ada pihak yang membutuhkan harus mendatangai secretariat DPC partai."

Dari beberapa pernyataan diatas dapat disimpulkan bahwa Pertanggungjawaban keuangan partai politik sudah berjalan dengan cukup baik Hal ini dibuktikan dengan penggunaan dana bantuan partai politik yang sesuai dengan fungsinya serta sudah bisa diakses oleh semua kalangan, namun untuk didaerah masih belum bisa diakses langung oleh semua kalangan, sehingga bagi yang membutuhkan atau ingin mengakses harus mendatangi langsung ke Kantor DPC Partai Gerindra di Daerah.

\section{Pertanggungjawaban Pengelolaan} Keuangan Partai Politik

Transparansi dan akuntabilitas merupakan konsep yang saling berkaitan, karena kedua hal ini berjalan searah. Pembuatan laporan keuangan partai politik merupakan salah satu bentuk dari kebutuhan transparansi dan merupakan syarat pendukung adanya 
akuntabilitas atas keterbukaan dari aktivitas pengelolaan keuangannya. Tujuannya untuk menjelaskan pertanggungjawaban atas penggunaan anggaran yang telah dikelola. Dengan adanya pelaporan dan pertanggung jawaban yang transparan, masyarakat menjadi tahu atas apa yang telah dilakukan partai, besaran anggaran yang digunakan dan hasilnya.

Partai politik yang merupakan organisasi nirlaba menerapkan akuntabilitas dalam pengelolaan keuangannya agar mampu memberikan pertanggungjawaban mengenai dana bantuan yang diberikan dari pemeritah, dana sumbangan dari donatur dan dana infaq dari anggota DPR. Pengurus partai politik harus memiliki skala prioritas atas kebutuhan yang mesti dipenuhi dengan memanfaatkan anggaran yang ada. Partai politik harus mengatur pengelolaan keuangan partai dalam
AD/ART. Pengelolaan dana dalam internal partai sangatlah menentukan eksistensi partai dalam perpolitikan.

Sebagai wujud transparansi publik, partai Gerindra dalam websitenya menginformasikan kegiatan maupun pertanggunggungjawab yang bisa diakses oleh semua kalangan. Keterbukaan informasi publik serta sebagai data yang memohon, partai Gerindra mempunyai fitur Fitru Permintaan Informasi Publik yang nantinya juga akan dipublikasikan di website tentang Laporan Akes Informasi Publik.

\section{Transparansi laporan keuangan} partai politik

Penyajian laporan keuangan partai politik harus secara transparan dan akuntabel yang berasal dari bantuan partai politik yang bersumber dari APBN maupun sumbangan para donatur yang telah mereka gunakan.

Gambar 2.

Website partai gerindra

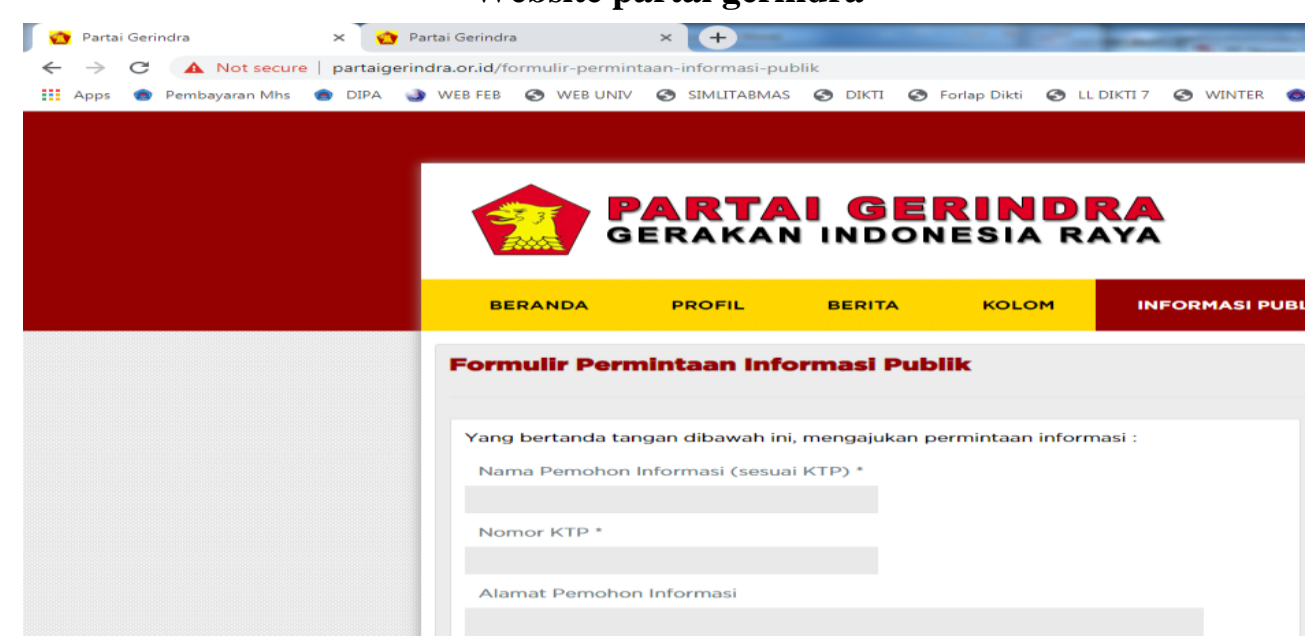

Sumber: http://partaigerindra.or.id/formulir-permintaan-informasi-publik 
Tabel 4.4

Prinsip Akuntabilitas dan transparansi Pengelolaan Keuangan Partai Politik Berdasarkan UU Nomor 2 Tahun 2011

\begin{tabular}{|c|c|c|c|}
\hline NO & Uraian & Hasil Penelitian & Ket \\
\hline 1 & $\begin{array}{l}\text { Kesesuaian } \\
\text { penggunaan } \\
\text { bantuan keuangan } \\
\text { partai dengan } \\
\text { peraturan } \\
\text { perundang- } \\
\text { undangan }\end{array}$ & $\begin{array}{l}\text { Hasil penelitian menunjukkan } \\
\text { bahwa pertanggungjawaban } \\
\text { terhadap sejumlah pemasukan } \\
\text { sebagaiman hasil Audit BPK } \\
\text { tahun } 2018 \text { sudah dipergunakan } \\
\text { sebagaimana yang seharusnya. }\end{array}$ & Berkesesuaian \\
\hline 2 & $\begin{array}{l}\text { Akuntabilitas dan } \\
\text { transparansi }\end{array}$ & $\begin{array}{l}\text { Hasil penelitian menunjukkan } \\
\text { bahwa partai telah membuat } \\
\text { sebuah mekanisme pengelolaan } \\
\text { keuangan yang terbuka kepada } \\
\text { publik, khususnya yang } \\
\text { mengatur bagaimana } \\
\text { masyarakat bisa mengakses } \\
\text { data dan informasi keuangan } \\
\text { mereka juga bagaimana parpol } \\
\text { secara aktif memberikan } \\
\text { informasi terbuka kepada } \\
\text { masyarakat. }\end{array}$ & $\begin{array}{l}\text { Sudah } \\
\text { transparan } \\
\text { namun masih } \\
\text { pada tingkat } \\
\text { pusat } \\
\text { sementara di } \\
\text { daerah masih } \\
\text { belum bisa } \\
\text { diakses secara } \\
\text { terbuka }\end{array}$ \\
\hline
\end{tabular}

PENUTUP

\section{Kesimpulan}

Kesimpulan yang dapat diambil dari hasil penelitian, maka didapat kesimpulan sebagai berikut:

1. Jumlah bantuan partai politik yang diterima telah sesuai dengan jumlah bantuan partai politik yang disalurkan oleh Kemendagri.

2. Penggunaan bantuan partai politik telah diprioritaskan untuk pelaksanaan pendidikan politik bagi anggota parpol dan masyarakat.

3. Pertanggungjawaban penerimaan dan pengeluaran bantuan partai politik yang bersumber dari APBN pada DPP Partai Gerakan Indonesia Raya telah sesuai dengan kriteria peraturan perundang-undangan yang berlaku.

4. Prinsip transparansi terkait pertanggungjawaban pengelolaan keuangan sudah dilakukan dan bisa di akses oleh semua kalangan melalui website resmi Partai Gerindra.

\section{Saran}

1. Prinsip transparansi terkait pertanggungjawaban keuangan hanya di tingkat pusat, sementara di Daerah masih belum di lakukan.

2. Pada website hanya ada menu LHKPN (Laporan Harta Kekayaan Pejabat Negara) namun masih belum di isi, seandainya menu ini bisa diisi dan bisa diakses maka informasi keterbukaan publik 
terkait pejabat dari Partai Gerindra

akan lebih baik dan menambah nilai positif bagi partai.

\section{DAFTAR PUSTAKA}

A. Bastian, I. (2017). Akuntansi Yayasan dan Lembaga Publik. Jakarta: Erlangga.

dpr.go.id. (2019, September 2019). Google. Retrieved Oktober 2019, 2019, from Website Resmi DPR RI:

http://www.dpr.go.id/anggota/ind ex/fraksi/8

Kompas.com. (2019, Agustus 31). Google. Retrieved Oktober 25, 2019, from Kompas.com: https://nasional.kompas.com/read/ 2019/08/31/11152361/hasillengkap-perolehan-kursi-dpr2019-2024?page $=$ all

KPU. (2018, April 20). Komisi Pemilihan Umum. Retrieved Februari 22, 2019, from Partai Politik Peserta Pemilu 2019: https://kpu.go.id/index.php/pages/ detail/2018/906
Neta, Y. (2011). Fungsi Partai Politik Dalam Pemilihan Umum yang Demokratis (Analisis Kritis terhadap Teori Fungsi Partai Politik). Jurnal Konsentrasi , 6786.

partaigerindra.or.id. (n.d.). Google. Retrieved Oktober 2019, 15, from Partai Gerindra: http://partaigerindra.or.id/sejarahpartai-gerindra

Sugiyono. (2019). Memahami Penelitian Kualitatif. Bandung: Alfabeta.

sumenepkab.go.id. (2018, Nopember 28). Google. Retrieved Oktober 2019, 16, from Website Resmi Kabupaten Sumenep: http://sumenepkab.go.id/berita/ba ca/banpol-sumenep-senilai-rp1miliar-lebih-sudah-cair

Supriyanto, D. d. (2012). Bantuan Keuangan Partai Politik Metode Penetapan Besaran, Transparansi dan Akuntabilitas Pengelolaan, Cetakan Pertama. Jakarta: Yayasan Perludem. 